\title{
KUALITAS PELAYANAN KESEHATAN \\ IBU HAMIL DAN BERSALIN DI DAERAH TERPENCIL (Studi Kasus di Nagari Batu Bajanjang, Kabupaten Solok, Provinsi Sumatera Barat)
}

\author{
The Quality of Health Services \\ for Pregnant Women and Maternity in Remote Area \\ (Case Studies in Nagari Batu Bajanjang, Solok District of West Sumatera Province)
}

\author{
Yulfira Media \\ Badan Perencanaan Pembangunan Daerah Provinsi Sumatera Barat \\ Khatib Sulaiman No. 1 Padang, Telp. (0751) 7054555-7055627 \\ Email: fira.media@yahoo.com
}

Dikirim: 15 Januari 2014; direvisi: 23Januari 2014; disetujui: 12 Februari 2014

\begin{abstract}
Abstrak
Penelitian ini bertujuan untuk mendeskripsikan bagaimana kualitas pelayanan kesehatan ibu hamil dan bersalin di daerah terpencil di Kabupaten Solok (Sumatera Barat). Penelitian ini menggunakan pendekatan kualitatif dengan teknik pengumpulan data melalui wawancara mendalam dan observasi. Hasil penelitian menunjukkan bahwa kualitas pelayanan kesehatan ibu hamil dan bersalin di lokasi penelitian masih relatif kurang, dan ini terlihat dari masih rendahnya pemanfaatan pelayanan kesehatan ibu hamil dan bersalin, yang salah satunya disebabkan oleh keterbatasan kondisi pelayanan kesehatan yaitu keterbatasan sumber daya dan pelayanan kesehatan, keterbatasan sarana dan prasarana kesehatan, dan adanya hambatan dalam pelaksanaan program jaminan persalinan (Jampersal). Temuan yang dapat diusulkan sebagai saran perbaikan meliputi: peningkatan monitoring dan evaluasi serta pembinaan secara berkala terhadap institusi pelayanan kesehatan, peningkatan kuantitas dan kualitas tenaga kesehatan, peningkatan ketersediaan pelayanan serta kondisi sarana dan prasarana kesehatan. Saran untuk mengatasi hambatan Jampersal adalah perlu adanya alokasi dana untuk sosialisasi kesehatan dan Jampersal, penyediaan kendaraan operasional (motor) untuk bidan serta perbaikan infrastruktur jalan.

Kata Kunci: pelayanan kesehatan, pemanfaatan, ibu hamil dan bersalin, daerah terpencil
\end{abstract}

\begin{abstract}
This study aims to describe how the quality of maternal health services and maternity in a remote area in Solok (West Sumatra). This study used a qualitative approach to data collection techniques through indepth interviews and observation. The results showed that the quality of maternal health services and maternity at the study site was relatively less, and is visible from the low utilization of maternal health services and maternity, which one of them caused by the limitations of the health conditions of limited resources and health services, limited health infrastructure, and the presence of obstacles in the implementation of the labor insurance program (Jampersal). The findings can be proposed as suggestions for improvement include: increase in monitoring and periodic evaluation and guidance to health care institutions, increasing the quantity and quality of health personnel, increasing the availability of services and infrastructure health condition. Suggestions for overcoming barriers Jampersal is the need for the allocation of funds for health and socialization Jampersal, providing operational vehicles (motorcycles) for midwives and improving road infrastructure.

Keywords: health care, utilization, pregnant women and maternity, remote areas
\end{abstract}

\section{PENDAHULUAN}

Angka kematian ibu (AKI) melahirkan di Indonesia masih dianggap tinggi jika dibandingkan dengan AKI di negara lain. Berdasarkan hasil Survey Kesehatan Demografi Indonesia (SDKI) tahun 2012 bahwa AKI di Indonesia mengalami peningkatan menjadi 359 kematian/100 ribu kelahiran hidup dari yang sebelumnya menurut SDKI tahun 200 adalah 228/100 ribu kelahiran. Padahal target Millenium Development Goals (MDGs) tahun 2015 adalah menurunkan angka kematian ibu sebesar tiga perempatnya (102/100.000 kelahiran hidup) pada tahun 2015 (BPS, 2013). Sebagian besar penyebab kematian adalah karena perdarahan, keracunan kehamilan dan infeksi pada masa nifas. Perdarahan disebabkan karena ibu hamil mengidap anemia. Sedangkan kematian ibu akibat infeksi menunjukkan adanya indikasi kurang baiknya upaya pencegahan manajemen infeksi, dan hal ini terkait dengan tenaga yang membantu persalinan (Afifah, dkk, 2010).

Berbagai upaya untuk menurunkan AKI telah banyak dilakukan, dan salah satu upaya terobosan yang paling mutakhir dari Kementerian Kesehatan sejak tahun 2011 adalah program Jampersal (Jaminan Persalinan) sebagai upaya menurunkan angka kematian ibu dan bayi menuju pencapaian target Millenium Development Goals (MDGs) tahun 2015. 
Adapun tujuan dari Jampersal tersebut adalah upaya untuk meningkatkan cakupan pemeriksaan kehamilan, pertolongan persalinan, dan pelayanan nifas ibu oleh tenaga kesehatan (Masadmin, 2011).

Walaupun beberapa upaya sudah dilakukan oleh pemerintah, namun pada kenyataannya AKI ibu di Provinsi Sumatera Barat masih tergolong tinggi, yaitu sebesar 212/per 100 ribu kelahiran hidup pada tahun 2012 (Bappeda, 2013). Kabupaten Solok merupakan kabupaten dengan angka kematian ibu tertinggi di Provinsi Sumatera Barat, yaitu sebesar 449.2/100.000 kelahiran hidup (Dinkes, 2008). Angka ini masih jauh dari bawah target MDGs 2015 yaitu 102/100.000 kelahiran hidup (Bappeda, 2011).

Permasalahan tingginya AKI di Indonesia juga disebabkan karena pelayanan pemeriksaan kehamilan dan pertolongan persalinan oleh tenaga profesional belum sepenuhnya dimanfaatkan oleh masyarakat, sehingga menyebabkan masih banyaknya ibu yang tidak melakukan pemeriksaan kehamilannya, dan tidak mendapatkan pemeriksaan kehamilan yang sesuai dengan standar program kesehatan ibu dan anak (Dewi, 2005). Selanjutnya juga merupakan kenyataan bahwa masih rendahnya akses terhadap pemanfaatan pertolongan persalinan oleh tenaga kesehatan, dan ini lebih terlihat pada masyarakat miskin di pedesaan (Ristirini, 2007).

Penyelenggaraaan urusan kesehatan di Indonesia berdasarkan UU Nomor 32 tahun 2004 (pasal 10) dan PP Nomor 38 tahun 2007 merupakan sinergi antara peran pemerintah

daerah dan pusat. Sistem Kesehatan Nasional menetapkan Puskesmas merupakan salah satu bentuk fasilitas pelayanan kesehatan. Pelayanan kesehatan yang diberikan oleh Puskesmas merupakan bagian dari pelayanan publik sebagaimana ditetapkan dalam Undang-Undang Nomor 25 tahun 2009 tentang Pelayanan Publik (Kemenkes, 2011).

Kecamatan Tigo Lurah adalah salah satu kecamatan di Kabupaten Solok yang merupakan daerah terpencil dan paling rendah dalam pemanfaatan pemeriksaan kehamilan dan pertolongan kesehatan dengan tenaga kesehatan. Berdasarkan data dari Dinas Kesehatan Kabupaten Solok diketahui bahwa pencapaian cakupan pemeriksaan kehamilan yang lengkap di Puskesmas Batu Bajanjang yang merupakan Puskesmas Kecamatan Tigo Lurah adalah hanya sebesar 40,4\%, sedangkan untuk cakupan pertolongan persalinan dengan tenaga kesehatan baru mencapai 40,6\% (Dinkes, 2012).

Menurut Hendrik L. Blum (Notoatmodjo, 2010) ada 4 faktor yang mempengaruhi status derajat kesehatan masyarakat atau perorangan, dan salah salah satunya adalah faktor pelayanan Kesehatan. Faktor pelayanaan kesehatan berpengaruh terhadap derajat kesehatan masyarakat karena keberadaan fasilitas kesehatan sangat menentukan dalam pelayanan pemulihan kesehatan, pencegahan terhadap penyakit, dan pengobatan kepada kelompok dan masyarakat yang membutuhkan pelayanan kesehatan.
Ketersediaan fasilitas dipengaruhi oleh keterjangkauan lokasi, dan juga dipengaruhi oleh tenaga kesehatan pemberi pelayanan, informasi dan motivasi masyarakat untuk mendatangi fasilitas dalam memperoleh pelayanan serta program pelayanan kesehatan itu sendiri apakah sesuai dengan kebutuhan masyarakat yang memerlukan. Berkaitan dengan hal ini, maka kualitas pelayanan dan kondisi rendahnya pemanfaatan pelayanan kesehatan dalam pemeriksaan kehamilan pertolongan persalinan juga dipengaruhi oleh faktor pelayanan kesehatan.

Hal yang tidak jauh berbeda juga diungkapkan oleh Green (Notoamodjo, 2010) bahwa ketersediaan sarana prasarana, sumber daya kesehatan dan pelayanan kesehatan adalah faktor pemungkin (enabling factors), yang memfasilitasi perilaku individu/masyarakat dalam pemanfaatan pelayanan kesehatan.

Selanjutnya menurut teori strukturasi Giddens bahwa struktur tidak hanya menghambat dan menentukan bentuk-bentuk tertentu perilaku, namun juga memberikan kemampuan bagi perilaku, artinya struktur memberikan peluang dan pembatasan sekaligus (Jones, 2010). Struktur menurut Giddens adalah aturan (rules) dan sumber daya (resources) yang terbentuk (dan membentuk) dari perulangan praktik sosial. Struktur tidak hanya dilihat sebagai sesuatu yang menghambat (constraining), tapi juga memberdayakan atau memberikan peluang terjadinya praktik sosial (enabling). Sedangkan agen dilihat Giddens sebagai "pelaku dalam praktik sosial". Agen bukan mengacu pada apa yang dimiliki, melainkan mengacu pada kemampuannya dalam melakukan sesuatu (Priyono, 2002).

Hasil penelitian Afifah, dkk, (2010) mengungkapkan bahwa kendala ibu hamil dalam melakukan akses pemeriksaan kehamilan di Kabupaten Sukabumi yaitu pelayanan kesehatan di Puskesmas/Polindes yang belum bisa menjangkau semua ibu yang bertempat tinggal di wilayah tersebut. Kondisi ini relatif banyak dirasakan oleh masyarakat yang bertempat tinggal di daerah yang wilayahnya cukup luas dan medannya relatif sulit untuk dijangkau.

Hasil penelitian dari Haryono (2013) di Madura juga terungkap bahwa di samping faktor sosial, budaya, dan ekonomi masyarakat serta keadaan geografis, faktor kesiapan pelayanan kesehatan baik secara kualitas maupun kuantitas menjadi pertimbangan masyarakat untuk memanfaatkan pelayanan kesehatan dalam pertolongan persalinan. Sehubungan dengan hal di atas, tujuan penelitian adalah untuk menggambarkan bagaimana kualitas pelayanan kesehatan ibu hamil dan bersalin di daerah terpencil di Nagari Batu Bajanjang, Kecamatan Tigo Lurah, Kabupaten Solok, Provinsi Sumatera Barat.

\section{METODE PENELITIAN}

Lokasi penelitian adalah di Nagari Batu Bajanjang, Kecamatan Tigo Lurah, Kabupaten Solok, 
Provinsi Sumatera Barat. Pemilihan lokasi didasarkan pertimbangan bahwa Kecamatan Tigo Lurah merupakan kecamatan yang terendah dalam pencapaian cakupan pemeriksaan kehamilan yang lengkap $(40,4 \%)$ dan persalinan dengan tenaga kesehatan (40,6\%). Kemudian secara purposive dipilih Nagari Batu Bajanjang karena dianggap bahwa cakupan pemeriksaan kehamilan dan pertolongan persalinan dengan tenaga kesehatan di Nagari Batu Bajanjang termasuk rendah. Penelitian dilakukan pada tahun 2013.

Penelitian ini merupakan penelitian lapangan yang berbentuk deskriptif-interpretatif dengan menggunakan pendekatan kualitatif. Data yang dikumpulkan adalah data primer dan data sekunder. Data primer dikumpulkan melalui wawancara mendalam kepada sejumlah informan. Informan dalam penelitian ini adalah kepala Puskesmas Batu Bajanjang, bidan koordinator Puskesmas Batu Bajanjang, tenaga kesehatan, ibu hamil atau ibu yang mempunyai anak balita, tokoh masyarakat, dan kader. Data sekunder diperoleh melalui studi kepustakaan dan dokumen dari Dinas Kesehatan dan instansi terkait, maupun sumber-sumber lain yang sesuai dengan standar keilmiahan.

Pengolahan dan analisis data dilakukan secara manual oleh peneliti dengan pendekatan kualitatif. Proses pengolahan dan analisis data dimulai dengan cara menelah seluruh data yang tersedia dari berbagai sumber, yaitu dari wawancara mendalam, observasi/pengamatan yang sudah dituliskan dalam catatan lapangan, dan dokumen resmi dari instansi terkait.

Selanjutnya analisis data dilakukan ke dalam tiga tahap, seperti yang dikemukakan oleh Miles dan Huberman (dalam Afrizal, 2008), yaitu tahap pertama adalah tahap kodifikasi data yang merupakan tahap di mana dilakukan koding terhadap data. Tahap kedua merupakan tahap lanjutan analisis, dimana peneliti melakukan kategorisasi data atau pengelompokkan data ke dalam klasifikasi-klasifikasi. Selanjutnya tahap ketiga adalah tahap lanjutan dimana pada tahap ini peneliti mencari hubungan antara kategori-kategori yang telah dibuat sebelumnya.

\section{HASIL DAN PEMBAHASAN}

\section{Pelaporan dan Pemanfaatan Sarana Kesehatan}

Nagari Batu Bajanjang adalah salah satu dari lima nagari yang terdapat di Kecamatan Tigo Lurah, Kabupaten Solok, dan merupakan salah satu daerah terisolir yang ada di wilayah Kabupaten Solok. Nari Batu Bajanjang memiliki jarak sekitar 96 km dari pusat pemerintahan Kabupaten Solok di Arosuka, dan berjarak sekitar $138 \mathrm{~km}$ dari Kota Padang sebagai Ibukota Provinsi Sumatera Barat. Waktu tempuh yang diperlukan dari Arosuka ke Nagari Batu Bajanjang jika menggunakan kendaraan roda empat adalah sekitar empat sampai dengan enam jam. Sedangkan waktu tempuh yang diperlukan dari Padang jika menggunakan kendaraan roda empat adalah sekitar tujuh sampai dengan sembilan jam.

Nagari Batu Bajanjang termasuk dalam wilayah kerja Puskesmas Batu Bajanjang, dan merupakan satu-satunya Puskesmas dengan kategori sangat terpencil di Kabupaten Solok. Kondisi geografis daerah ini berbukit-bukit dan sebagian jalan menuju lokasi adalah jalan tanah dan batu-batu yang relatif sulit untuk ditempuh dengan kendaraan roda empat. Sebagian besar masyarakat di Nagari Batu Bajanjang mempunyai latar belakang pendidikan yang relatif rendah, tidak tamat Sekolah Dasar dan tamat Sekolah Dasar (84,33\%). Sedangkan mereka yang mempunyai tingkat pendidikan tinggi (sarjana) relatif sangat kecil, yaitu sebesar $0,52 \%$.

Ditinjau dari mata pencaharian penduduk, sebagian besar masyarakat di Nagari Batu Bajanjang mempunyai mata pencaharian sebagai petani, yaitu sebanyak $97,41 \%$. Dalam bidang pertanian ini dapat dikatakan bahwa pada umumnya masyarakat bekerja sebagai petani sawah dengan penghasilan yang relatif kurang memadai dan cenderung cukup untuk

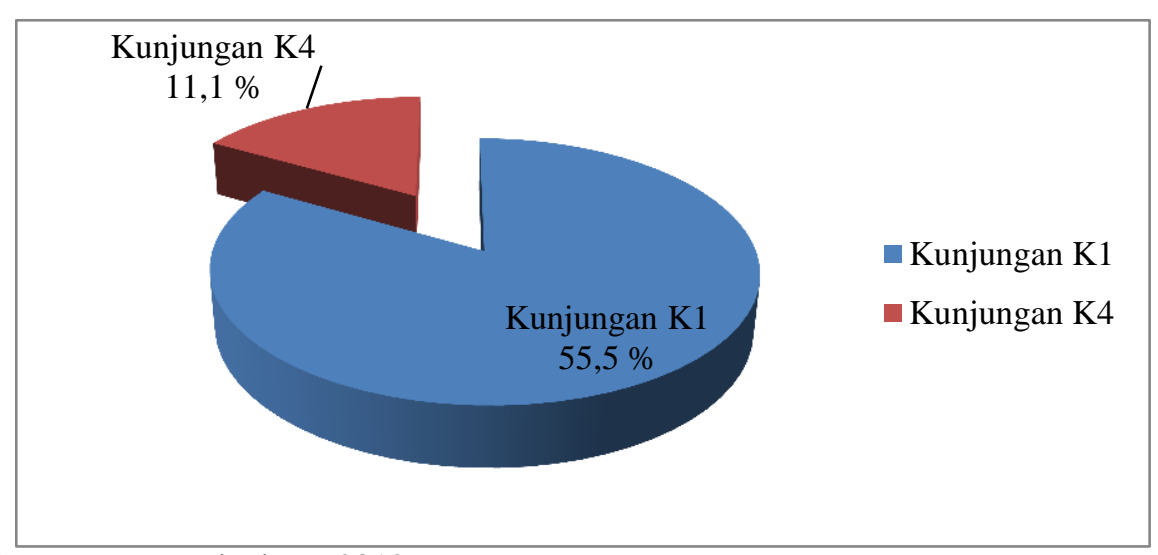

Sumber:Puskesmas Batu Bajanjang, 2012

Gambar 1. Persentase Cakupan Pemeriksaan Kehamilan 


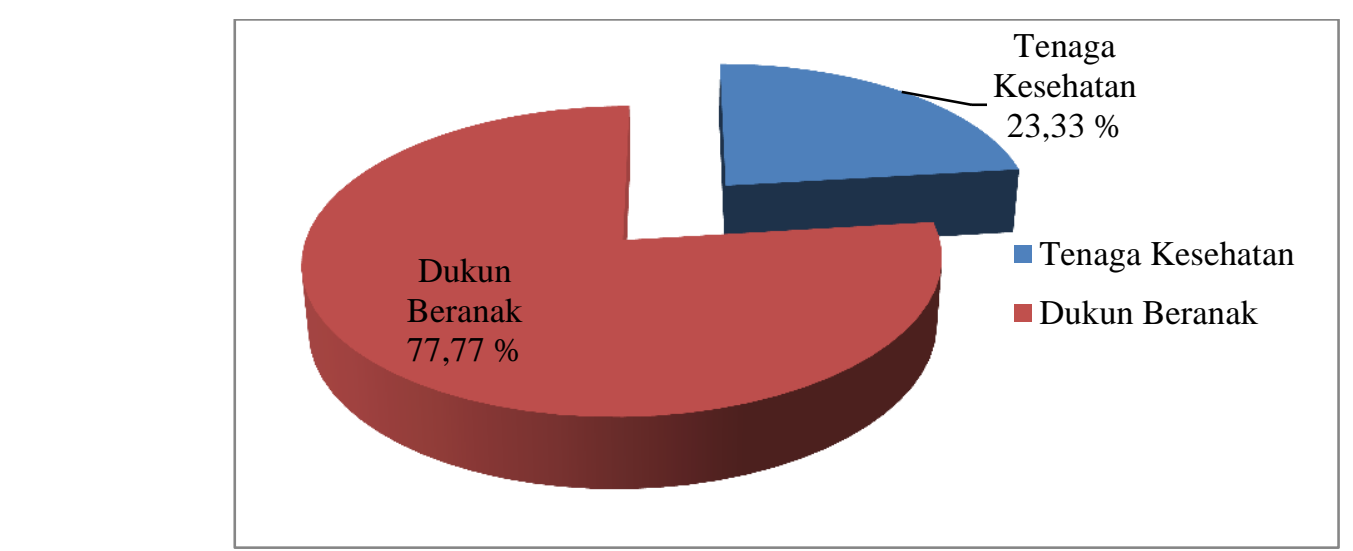

Sumber: Puskesmas Batu Bajanjang, 2012

Gambar 2. Persentase Cakupan Persalinan

memenuhi kehidupan sehari-hari.

Gambaran mengenai kualitas pelayanan kesehatan ibu hamil dan bersalin di Nagari Batu Bajanjang, Kecamatan Tigo Lurah, Kabupaten Solok dapat dikemukakan dari rendahnya pemanfaatan pelayanan kesehatan ibu hamil dan bersalin. Selanjutnya dalam hal ini juga dikemukakan mengenai faktor kondisi pelayanan kesehatan yang merupakan salah satu penyebab rendahnya pemanfaatan pelayanan kesehatan. Berkaitan dengan partispasi masyarakat dalam memanfaatkan pelayanan kesehatan tersebut, dari hasil penelitian diketahui bahwa masyarakat di lokasi penelitian mempunyai kecenderungan kurang memanfaatkan pelayanan kesehatan, baik dalam pemeriksaan kehamilan maupun pertolongan persalinan. Hal ini bisa terlihat dari Gambar 1 bahwa data kunjungan pemeriksaan pertama kali (K1) di Nagari Batu Bajanjang adalah sebesar 55,5\%, sedangkan untuk kunjungan K4 hanya sebesar $11,1 \%$. Hal ini menurut informan disebabkan karena ibu hamil belum memanfaatkan pelayanan secara optimal, dan pemeriksaan kehamilan cenderung dilakukan jika ada keluhan, dan biasanya pemeriksaan kehamilan mulai dilakukan pada usia kehamilan 5 atau 6 bulan.

Gambaran mengenai cakupan persalinan yang ditolong oleh tenaga kesehatan di Nagari Batu Bajanjang tahun 2012 menurut informan (tenaga kesehatan) relatif rendah, yaitu 23,33\%. Sedangkan data cakupan persalinan dengan dukun relatif tinggi, yaitu sebesar 77,77\% (seperti terlihat pada Gambar 2).

\section{Kondisi Pelayanan Kesehatan}

Salah satu penyebab rendahnya pemanfaatan pelayanan kesehatan dalam pemeriksaan kehamilan dan persalinan adalah berkaitan dengan faktor kondisi pelayanan kesehatan, yang meliputi keterbatasan sumber daya dan pelayanan kesehatan, sarana prasarana kesehatan serta adanya hambatan dalam pelaksanaan Jamin Persalinan (Jampersal).

\section{Keterbatasan Sumber Daya dan Pelayanan Kesehatan}

Ketersediaan sumber daya kesehatan yang terdapat di wilayah kerja Puskesmas Batu Bajanjang menurut informan relatif sangat kurang, baik dari segi kuantititas maupun kualitasnya. Jumlah tenaga kesehatan yang bertugas di wilayah kerja Puskesmas Batu Bajanjang terdapat adalah sekitar 24 orang. Tenaga kesehatan tersebut bertugas di Puskesmas dan Puskesmas Pembantu (Pustu) serta Pos Kesehatan nagari (Poskesri) yang tersebar di beberapa nagari di Kecamatan Tigo Lurah, dan termasuk Nagari Batu Bajanjang.

Jumlah tenaga kesehatan (bidan) di Nagari Batu Bajanjang yang dianggap mempunyai kompetensi dalam membantu persalinan relatif sedikit, yaitu satu orang dokter PTT, dua orang bidan (bidan PTT dan PNS) di Puskesmas dan satu bidan PNS di Poskesri. Dari tenaga kesehatan yang tersedia ini, ada yang tidak bisa melaksanakan tugasnya karena sedang menjalankan cuti melahirkan. Dengan kata lain ada Poskesri (Poskesri Muaro) yang pada waktu dilakukan penelitian tidak memiliki tenaga bidan atau tidak buka pelayanan, sehingga masyarakat yang berada di sekitar Poskesri tersebut tidak bisa memanfaatkan pelayanan kesehatan di tempat tersebut. Kekurangan jumlah tenaga kesehatan tersebut menurut kepala Puskesmas dari tahun ke tahun memang menunjukkan penurunan, dan ini sebagai akibat dari cukup banyaknya tenaga kesehatan yang keluar, tetapi sampai saat ini belum ada penggantinya.

Jika dilihat dari segi kualitasnya, tenaga kesehatan (tenaga bidan) yang bertugas di Nagari Batu Bajanjang juga relatif kurang. Sebagian besar tenaga bidan yang bertugas di Batu Bajanjang adalah masih relatif muda, baru beberapa tahun lulus, belum lama bertugas dan belum banyak pengalaman. Tenaga bidan tersebut menurut informan (kepala Puskesmas) lebih banyak berasal dari luar daerah (pendatang), dan bertempat tinggal di Kota Solok karena memang keluarganya yang bertempat tinggal di Kota Solok.

Tenaga kesehatan dalam melaksanakan tugasnya untuk memberikan pelayanan kepada masyarakat tampaknya tidak sesuai dengan aturan yang seharusnya. Dari hasil observasi dan wawancara 
mendalam diketahui bahwa tenaga kesehatan tidak bisa memberikan pelayanan optimal, artinya pelayanan yang diberikan oleh tenaga kesehatan terbatas atau pada hari-hari tertentu saja. Jadwal pelayanan kesehatan di Puskesmas cenderung hanya dibuka pada hari Selasa dan Rabu, dan tentunya hal ini tidak sesuai dengan jadwal yang seharusnya, yaitu setiap hari kerja (hari Senin sampai dengan Jumat). Bahkan pada waktu kunjungan penulis pada hari Selasa ke lokasi penelitian, tampak bahwa Puskesmas pada hari Selasa tersebut tutup, dan baru dibuka pada keesokan harinya (hari Rabu). Padahal menurut informan (tokoh masyarakat) kepala Puskesmas adalah berasal dari putra daerah setempat, dan tenaga kesehatan seperti perawat juga berasal dari daerah setempat. Namun hal ini menurut informan terkesan dibiarkan saja, dan menyesuaikan dengan kebiasaan tenaga kesehatan yang dari luar daerah setempat. Adanya rasa kekecewaan masyarakat terhadap kondisi tersebut seperti yang diungkapkan informan sebagai berikut: "Masyarakat hanya bisa mendapatkan pelayaan di Puskesmas pada hari tertentu saja yaitu hari Selasa dan Rabu saja, karena petugas kesehatan biasanya datang selasa sore, dan kembali lagi ke tempat tinggal mereka pada hari Rabu sore atau Kamis pagi. Istilahnya sekarang ini SR (Selasa Rabu)".

Ketidaktaatan tenaga kesehatan dan keterbatasan layanan kesehatan di fasilitas kesehatan seperti di Puskesmas tersebut juga dianggap ada kaitannya dengan belum adanya aturan yang jelas mengenai tugas dan tanggung jawab dari masingmasing petugas kesehatan. Hasil wawancara dengan beberapa tenaga kesehatan di Puskesmas terungkap bahwa belum ada pembagian tugas yang jelas untuk setiap petugas yang ada di puskesmas. Hal ini seperti yang diungkapkan informan sebagai berikut: "Untuk melaksanakan pekerjaan di Puskesmas dirasakan sangat perlu adanya aturan pembagian kerja yang jelas dan harus diikuti oleh semua tenaga yang bekerja. Namun, di sini ada tenaga yang mengerjakan semua pekerjaan, ada pula tenaga yang tidak melakukan apaapa."

Kondisi yang demikian tentunya berdampak kepada motivasi dan kepatuhan petugas kesehatan untuk menjalankan tugas.

Sementara itu, tenaga bidan yang bertugas di Poskestri diharapkan mampu untuk bisa melakukan pendekatan atau menyesuaikan diri dengan kondisi karakteristik sosial budaya lokal. Namun dalam kenyataannya hal ini sulit tampaknya mereka lakukan. Bidan dianggap kurang bisa melakukan pendekatan dengan masyarakat setempat, di mana interaksi yang dilakukan bidan dengan penduduk setempat relatif kurang. Hal ini tentu ada kaitannya dengan kehadiran bidan di daerah setempat yang dianggap masyarakat relatif kurang. Kondisi keterbatasan layanan inilah yang menyebabkan ibu hamil yang ingin memeriksakan kehamilannya dan meminta bantuan persalinan lebih memilih pelayanan kesehatan tradisional (dukun beranak).

Perilaku tenaga kesehatan yang berkaitan dengan kurangnya kinerja dan kehadiran mereka di tempat bekerja menurut informan (tenaga kesehatan) disebabkan oleh beberapa hal, antara lain karena kondisi lingkungan tempat tinggal mereka yang kurang dianggap nyaman. Kondisi sarana dan prasarana yang terdapat di rumah dinas tempat tinggal mereka relatif terbatas, di mana listrik dan air untuk kebutuhan mandi dan masak cenderung tidak tersedia setiap saat serta cenderung kekurangan air, sehingga harus mandi di sungai. Di samping itu, mereka juga merasa terganggu karena ada masyarakat yang dianggap terkadang mengganggu ketenangan mereka, seperti mencuri alat-alat elektronik. Hal-hal seperti inilah yang membuat mereka cenderung tidak bisa berlama-lama dan cenderung untuk cepat pulang ke Solok.

Alasan lainnya kenapa bidan merasa tidak betah di tempat adalah karena mereka beranggapan bahwa keberadaan mereka sebagai tenaga kesehatan di lingkungan daerah setempat kurang mendapat respon dari masyarakat. Selama menjalankan tugas (sekitar) empat tahun, informan belum pernah menjalankan tugas untuk membantu persalinan. Masyarakat cenderung lebih mempercayai dan memanfaatkan jasa tenaga dukun beranak. Pengalaman yang diharapkannya setelah lulus bekerja tampaknya relatif sulit didapatkannya. Hal ini berbeda ketika informan pulang ke Solok, pengalaman untuk membantu persalinan bisa diperolehnya ketika dia membantu persalinan warga di sekitar tempat tinggalnya. Hal ini seperti yang dikemukakan informan sebagai berikut: "Rasa-rasanya sulit mendapatkan pengalaman untuk membantu persalinan di daerah ini, karena masyarakat cenderung mempercayai dukun. Sebagai tenaga bidan memang dirasakan sulit untuk menghadapi kondisi masyarakat seperti ini, dan apalagi dukun beranak juga mempunyai kemampuan yang lebih dan bisa menahan kelahiran. Tapi saya merasakan mendapatkan pengalaman ketika membantu persalinan di di sekitar tempat tinggal di Solok".

Keterbatasan jumlah sumber daya kesehatan dan terbatasnya ketersediaan pelayanan ini tentu dapat mempengaruhi motivasi masyarakat untuk tidak memanfaatkan pelayanan kesehatan dalam pemeriksaan kehamilan dan pertolongan persalinan.

Sementara itu, ketika ditemukan kasus-kasus persalinan yang tidak bisa ditangani oleh dukun, dan bidan tidak berada ditempat, maka persalinan terpaksa harus dilakukan oleh perawat yang kebetulan berasal putra daerah. Sebagai seorang perawat dia menyadari bahwa bukan tugas pokoknya untuk membantu persalinan. Namun, karena masyarakat meminta bantuan untuk menangani persalinan, maka dengan bekal pengalaman yang didapatkan pada waktu bidan membantu persalinan dia memberanikan diri untuk membantu persalinan. Mengenai hal ini menurut pihak 
Puskesmas tidak ada larangan, karena tenaga perawat dari putra daerah tersebut dianggap bisa membantu persalinan. Kondisi seperti ini kalau dibiarkan terus tentunya beresiko terhadap kesehatan ibu dan anak. Hal ini menurut informan (ibu hamil) sudah ada kasus kematian bayi (bayinya meninggal di dalam) dan tenaga penolong persalinannya adalah perawat.

Kondisi relatif terbatasnya ketersediaan pelayanan yang diberikan oleh tenaga kesehatan di Puskesmas inilah yang mengakibatkan motivasi masyarakat untuk memanfaatkan pelayanan kesehatan untuk ibu hamil dan bersalin menjadi berkurang, dan akhirnya masyarakat tetap memanfaatkan dukun beranak sebagai tenaga penolong persalinan yang siap dipanggil saja dan sudah berpengalaman.

\section{Keterbatasan Sarana dan Prasarana Kesehatan}

Puskesmas Batu Bajanjang sebelumnya merupakan Puskesmas Pembantu dari Puskesmas Induk di Sirukam. Kemudian semenjak tahun 2004 Pustu tersebut sudah berubah menjadi Puskesmas Batu Bajanjang. Berdasarkan hasil observasi di Puskesmas Batu Bajanjang, bangunan Puskesmas terlihat kurang terawat dengan baik, yang mana beberapa bagian bangunan dalam kondisi retak.

Berdasarkan hasil observasi di lapangan tampak bahwa kondisi penataan ruangan Puskesmas yang dijadikan sebagai tempat pelayanan tampaknya belum ditata dengan baik. Hal ini terlihat dari beberapa ruangan yang terdapat di Puskesmas belum jelas pengaturannya, mana ruangan yang digunakan untuk pendaftaran/pengambilan karcis, pemeriksaan kesehatan, ruangan rawatan, apotik dan ruangan program lainnya.

Prasarana pendukung seperti listrik dan air bersih juga dirasakan pemakaiannya relatif terbatas. Listrik biasanya hanya bisa dimanfaatkan pada waktu malam hari, yang mana jadwalnya dimulai pada jam 18.00 WIB sampai dengan 07.00 WIB, sedangkan pemakaian air untuk kebutuhan air minum, memasak dan mandi dialirkan dari sumber mata air yang berada pada ketinggian yang tidak jauh di seberang Puskesmas. Jika kondisi pipa aliran air tersebut mengalami kerusakan, maka kebutuhan air untuk Puskesmas terpaksa dengan memanfaatkan sumber air yang berasal dari aliran sungai yang berada di belakang Puskesmas. Jika kondisi ini terjadi, maka tentu saja dapat berpengaruh terhadap kualitas pelayanan kesehatan Puskesmas. Disamping itu, hal tersebut juga berdampak buruk terhadap motivasi petugas dalam melakukan pekerjaan dan bertempat tinggal di rumah dinas yang disediakan.

Alat-alat kesehatan dan obat-obatan dirasakan juga masih kurang. Ketika masyarakat berobat ke Puskesmas, tenaga kesehatannya mengatakan obatnya tidak tersedia di Puskesmas, sehingga pasien harus membayar obat yang disediakan secara pribadi oleh tenaga kesehatan. Alasan yang diungkapkan informan (tenaga kesehatan) mengenai hal tersebut adalah karena beberapa obat dasar yang harus disediakan pihak Puskesmas tidak tersedia, sehingga terpaksa diberikan obat sendiri. Padahal motivasi masyarakat untuk memanfaatkan Puskesmas adalah karena biayanya lebih murah atau gratis. Hal ini kalau lamalama dibiarkan tentunya bisa mengakibatkan keinginan masyarakat untuk mendapatkan pengobatan yang murah menjadi berkurang.

Sarana Pelayanan kesehatan untuk di luar gedung Puskesmas, dilengkapi dengan satu unit mobil Puskesmas keliling double garden yang dapat menjangkau daerah-daerah sulit dan medan yang berat. Mobil ini juga biasanya dimanfaatkan untuk mengantarkan pasien yang dalam kondisi darurat, dan yang harus segera mendapatkan pertolongan atau harus dirujuk ke rumah sakit.

Kondisi sarana prasarana pelayanan kesehatan lainnya seperti Poskesri yang ada di wilayah kerja Batu Bajanjang juga tidak jauh berbeda. Kondisi sarana dan prasarana yang terdapat di Poskesri tampaknya juga relatif kurang memadai, ruangan pemeriksaannya relatif kecil, dan obat-obatan yang tersedia juga relatif sedikit, dan tidak terawat. Poskesri sendiri karena kehadiran bidan yang terbatas, maka cenderung tidak berfungsi atau ditutup saja. Kondisi pelayanan yang kurang memadai tersebut tentunya juga dapat mempengaruhi persepsi masyarakat dalam pemanfaatan pelayanan kesehatan.

Sarana tranportasi umum yang dapat digunakan masyarakat untuk berobat ke Puskesmas sangat terbatas. Sebagian besar jenis transportasi yang tersedia adalah kendaraan roda dua berupa ojek, dan biaya yang harus dikeluarkan masyarakat jika lokasinya jauh dari Puskesmas relatif cukup mahal.

Berdasarkan hasil observasi di beberapa ruangan Puskesmas Batu Bajanjang, tampak bahwa standar ataupun pedoman pelaksanaan program yang digunakan sebagai acuan dalam pelaksanaan program belum ditata dan tersedia dengan baik. Selanjutnya jika ditanyakan tentang data-data/dokumen perencanaan, hasil monitoring dan evaluasi, dan dokumen pencapaian program belum bisa ditunjukkan oleh pihak petugas sebagaimana yang diharapkan/sesuai standar.

\section{Hambatan dalam Pelaksanaan Jampersal}

Program Jampersal yang sudah diluncurkan tahun 2011, menurut kepala Puskesmas masih belum banyak membantu dalam meningkatkan pemanfaatan pelayanan kesehatan, khususnya meningkatkan cakupan pemeriksaan kehamilan dan persalinan oleh tenaga kesehatan.

Beberapa hambatan dalam pelaksanaan Jampersal antara lain adalah masalah kurangnya sosialisasi yang dilakukan tenaga kesehatan kepada masyarakat. Hal ini terkait dengan tidak adanya alokasi dana untuk melakukan sosialisasi. Kondisi inilah yang menyulitkan tenaga kesehatan untuk melakukan sosialisasi atau penyuluhan kesehatan termasuk tentang Jampersal, dan apalagi mengingat 
kondisi geografis yang relatif sulit untuk ditempuh serta ditambah lagi dengan jarak satu rumah dengan rumah yang lain letaknya berjauhan.

Hambatan lainnya adalah masalah keterlambatan tenaga kesehatan untuk mengetahui bahwa ada ibu yang hamil dan tidak berkunjung ke fasilitas kesehatan. Dalam hal ini tenaga kesehatan cenderung baru mengetahui kalau kondisi ibu hamil mau melahirkan serta tidak bisa ditangani dukun. Bagi masyarakat yang tidak datang ke fasilitas pelayanan kesehatan, akhirnya petugas sendirilah yang harus datang ke rumah ibu yang mau melahirkan tersebut.

Bidan sebagai tenaga penolong persalinan, tentunya mempunyai tugas untuk membantu persalinan. Namun dalam pelaksananaannya bidan merasakan adanya kendala dengan masalah biaya transportasi, karena Puskesmas memang tidak ada menyediakan kendaraan dan biaya operasional untuk hal tersebut. Apalagi jika kondisi rumah yang akan dikunjungi letaknya sangat jauh dan keluarga dan bidan harus menyewa ojek dengan ongkos yang relatif mahal yang terkadang sampai mencapai Rp 200.000 (pulang-pergi). Hal inilah yang menjadi kendala bagi bidan untuk melaksanakan persalinan yang letaknya jauh dan di luar wilayah tugas mereka.

Masyarakat yang sudah mengetahui Jampersal beranggapan bahwa setiap persalinan yang dilakukan oleh tenaga kesehatan gratis. Namun jika yang membantu persalinan adalah perawat (putra daerah) karena bidan tidak ada di tempat, mereka tetap dipungut biaya persalinan, bahkan bisa sampai Rp. $800.000,-$. Masyarakat tidak tahu bahwa perawat yang membantu persalinan bukanlah termasuk tenaga yang berkompeten dalam melakukan persalinan. Perawat tidak bisa melakukan klaim terhadap persalinan yang sudah dilakukan, sehingga masyarakat harus membayar biaya persalinan. Kondisi seperti ini juga menjadi kendala bagi masyarakat dalam memanfaatkan Jampersal, dan lebih baik memilih dukun beranak yang biayanya lebih terjangkau.

\section{HASIL DAN PEMBAHASAN}

Gambaran kondisi pelayanan kesehatan yang telah dikemukakan di atas memperlihatkan bahwa keterbatasan sumber daya kesehatan, sarana prasarana kesehatan, obat-obatan dan ketersediaan pelayanan kesehatan yang terbatas tentunya dapat memberikan pengaruh terhadap motivasi masyarakat dalam pemanfaatan pelayanan kesehatan ibu hamil dan bersalin. Hal ini seperti yang dikemukakan oleh Green (Notoamodjo, 2010) bahwa ketersediaan sarana prasarana, sumber daya kesehatan dan pelayanan kesehatan adalah faktor pemungkin, yang memfasilitasi perilaku individu/masyarakat dalam pemanfaatan pelayanan kesehatan.

Contoh kasus yang menunjukkan bahwa tenaga kesehatan tidak bisa memberikan pelayanan yang sesuai dengan aturan dan jadwal pelayanan yang cenderung dilakukan pada hari Selasa dan Rabu tersebut dapat dijelaskan dengan menggunakan teori strukturasi Giddens. Dalam hal ini tenaga kesehatan sebagai agen yang berpengetahuan banyak mengetahui bahwa masyarakat mempunyai kebiasaan untuk memanfaatkan pelayalanan kesehatan pada hari Rabu, yaitu hari pasar. Pada hari Rabu ini memang masyarakat cenderung pergi ke Puskesmas atau ke Poskesri, karena ini sengaja dilakukan bersamaan dengan aktifitas untuk pergi ke pasar (balai). Sedangkan pada hari-hari lainnya petugas kesehatan juga telah memonitor bahwa masyarakat jarang yang memanfaatkan pelayanan kesehatan. Melihat adanya peluang bahwa masyarakat cenderung pergi ke pelayanan kesehatan pada waktu hari pasar tersebut, maka petugas kesehatan memperhitungkan kondisi stuktural dilingkungannya dan memilih memanfaatkan peluang tersebut untuk menyiasati atau mengambil keuntungan dari kondisi tersebut. Dengan tidak adanya aturan yang tegas dari pimpinan, maka petugas kesehatan yang seharunya mempunyai tugas dan tanggung jawab melayani masyarakat pada setiap hari kerja, kemudian ditranformasi atau direkontruksi lagi. Hal ini tentunya melalui kesepakatan bersama, sehingga jadwal pelayanan di Puskesmas cenderung dibuka pada hari Selasa dan Rabu. Pada hal tersedianya sarana dan prasarana untuk mendukung kesehatan masyarakat merupakan salah satu komponen dalam mempromosikan kesehatan dalam masyarakat itu sendiri. Ketersediaan sarana dan prasarana ini dapat dilihat langsung oleh masyarakat, sehingga masyarakat ingin mencoba dan merasakan langsung apa mereka lihat ( Tesis Murniati, 2008)

Berkaitan dengan kasus tenaga kesehatan sebagai agen yang sulit untuk bertahan lama di daerah lokasi tempat mereka ditugaskan, maka dengan mengikuti pemikiran Giddens, dapat dijelaskan bahwa keterbatasan kondisi sarana prasarana di rumah tempat tinggal mereka, letaknya yang terpencil dan kurangnya kepedulian masyarakat terhadap kehadirannya menjadi suatu alasan dan motivasi kenapa agen (pelaku) sulit bisa bertahan lama. Apalagi hal ini menurut informan didukung oleh tidak adanya aturan yang tegas dari pimpinan Puskesmas untuk menertibkan bahwa pegawai harus hadir setiap hari di fasilitas kesehatan. Kalau sesuai aturan, tenaga kesehatan tentunya harus hadir pada setiap hari kerja. Namun, aturan yang seharusnya dipatuhi, tidaklah secara ketat mengekang tindakan seseorang. Agen dengan kreativitas yang dimilikinya dapat menyisiasati sebagai upaya untuk mempengaruhi struktur yang ada. Dalam hal ini ada peluang untuk mempengaruhi struktur yang ada. Perubahan yang terjadi struktur atau aturan bisa diubah dan dimodifikasi yang membawa pengaruh kepada pelaku, di mana struktur tidak dimaknai menghambat tapi bisa memberikan peluang dan bisa memberikan keuntungan kepada tenaga kesehatan karena jadwal pelayanan kesehatan cenderung tersedia pada hari Selasa dan Rabu saja. 
Berdasarkan gambaran dan pengalaman dari aktor yang terlibat dalam tindakan pertolongan persalinan, maka dapat dikatakan bahwa program Jampersal yang tujuannya untuk meningkatkan cakupan pemeriksaan kehamilan dan pertolongan persalinan dengan tenaga kesehatatan tidak bisa dilaksanakan secara maksimal. Program tersebut terkendala dengan keterbatasan dana untuk melaksanakan sosialisasi, dan tidak adanya dana untuk biaya transportasi bidan ke rumah ibu hamil karena kebiasaan masyarakat yang melahirkan di rumah bukan di tempat fasilitas kesehatan. Jika mengikuti pandangan Giddens, maka keterbatasan alokasi dana (struktur) tersebut memberikan peluang juga bagi bidan untuk lebih memilih persalinan yang tidak menggunakan Jampersal. Bidan sebagai agen merasionalkan kehidupannya sebagai upaya untuk mencari perasaan aman. Sementara itu, ibu hamil yang merasakan keberatan dengan biaya persalinan yang sudah ditentukan tenaga kesehatan juga akan mencari peluang untuk memilih dukun beranak yang biayanya lebih terjangkau. Dengan demikian apa yang dikatakan oleh Giddens bahwa struktur tidak hanya mengekang, tapi juga memberikan peluang terjadinya praktik sosial.

Berbagai persoalan yang terkait dengan rendahnya kualitas pelayanan kesehatan ibu hamil dan bersalin seperti yang telah dikemukakan di atas perlu diupayakan jalan keluarnya agar kualitas pelayanan kesehatan tersebut bisa ditingkatkan dan motivasi masyarakat untuk memanfaatkan pelayanan kesehatan ibu hamil dan bersalin juga bisa meningkat. Beberapa alternatif kebijakan yang bisa diusulkan diantaranya adalah dengan melakukan peningkatan monitoring dan evaluasi serta pembinaan terhadap institusi pelayanan kesehatan secara berkala, peningkatan kuantitas atau jumlah dan kualitas tenaga kesehatan, peningkatan ketersediaan pelayanan kesehatan dengan menyediakan layanan setiap hari kerja, dan peningkatan kondisi sarana dan prasana kesehatan. Selanjutnya alternatif saran yang dapat diusulkan untuk mengatasi hambatan pelaksanaan Jampersal adalah dengan menyediakan alokasi dana untuk kegiatan sosialisasi kesehatan dan Jampersal, menyediakan kendaraan operasional bagi tenaga bidan berupa kendaraan roda dua, sehingga bidan tidak lagi merasa keberatan untuk mengeluarkan biaya transportasi (sewa kendaraan) dalam menangani persalinan yang menggunakan Jampersal. Kemudian untuk mempermudah akses pelayanan kesehatan juga perlu adanya perbaikan infrastruktur jalan.

\section{SIMPULAN}

Berdasarkan hasil penelitian dan pembahasan tersebut di atas tampak bahwa kualitas pelayanan kesehatan ibu dan hamil di daerah lokasi penelitian masih belum sesuai dengan yang diharapkan. Hal ini terlihat dari gambaran masih rendahnya pemanfaatan pelayanan kesehatan ibu hamil dan bersalin yang disebabkan oleh berbagai persoalan kondisi pelayanan kesehatan, seperti tercermin dari keterbatasan dalam sumber daya kesehatan dan ketersediaan pelayanan kesehatan. Keterbatasan sumber daya terlihat dari keterbatasan jumlah dan kualitas tenaga kesehatan yang tersedia (bidan relatif masih relatif muda, belum banyak pengalaman dan cenderung tidak berada di tempat) serta terbatasnya ketersediaan pelayanan kesehatan, yang mana pelayanan cenderung hanya tersedia dua kali dalam satu minggu. Selanjutnya kondisi pelayanan kesehatan juga terkait dengan keterbatasan dari kondisi sarana dan prasarana kesehatan serta adanya berbagai hambatan dalam pelaksanaan Jaminan Persalinan seperti kurangnya sosialisasi dan tidak adanya alokasi dana untuk sosialisasi, tidak tersedianya biaya transportasi untuk tenaga bidan dan kesulitan untuk mencapai akses pelayanan.

\section{Saran}

Beberapa saran yang dapat diusulkan dalam upaya peningkatan kualitas pelayanan kesehatan ibu hamil dan bersalin antara lain adalah dengan upaya peningkatan monitoring dan evaluasi serta pembinaan dari Dinas Kesehatan Kabupaten secara berkala, mengusulkan permintaan tambahan tenaga bidan melalui Kementerian Daerah Tertinggal, meningkatkan kualitas tenaga kesehatan khususnya bidan melalui beberapa pelatihan agar mereka lebih percaya diri dan bisa menyesuaikan dengan kondisi sosial budaya setempat. Perlu adanya peningkatan ketersediaan pelayanan kesehatan (pelayanan harus bisa tersedia setiap hari kerja) dan peningkatan kondisi sarana serta prasarana kesehatan. Selanjutnya saran yang bisa diusulkan untuk mengatasi hambatan Jampersal adalah pihak terkait (Dinas Kesehatan Provinsi dan Kabupaten) perlu menyediakan alokasi dana untuk sosialisasi/promosi kesehatan dan Jampersal dan penyediaan kendaraan operasional (roda dua) untuk bidan. Kemudian perlu adanya perbaikan infrastruktur jalan dari Dinas Prasarana Jalan.

\section{DAFTAR PUSTAKA}

Afifah,Tin, Pangaribuan, L, Rachmalina, dan Media, Yulfira. 2010. Perilaku Pemeriksaan Kesehatan Ibu Hamil dan Pemilihan Pertolongan Persalinan di Kabupaten Sukabumi. Jurnal Ekologi Kesehatan, Volume 9, No. 3 September 2010. Jakarta, Badan Litbang Kesehatan.

Afrizal, 2008. Pengantar Metode Penelitian Kualiatatif. Padang: Laboratorium Sosiologi Fisip Unand.

Badan Perencanaan Pembangunan Daerah Provinsi Sumatera Barat. 2011. Peraturan Daerah Provinsi Sumatera Barat Nomor 5 Tahun 2011 tentang Rencana Pembangunan Jangka 
Menengah (RPJM) Derah Provinsi Sumatera Barat.

Badan Pusat Statistik. 2013. Survey Kesehatan Indonesia 2012

Dinas Kesehatan Provinsi Sumatera Barat. 2008. Studi Kematian Ibu dan Kematian Bayi di Propinsi Sumatera Barat tahun 2007 Faktor Determinan dan Permasalahannya. Padang: Laporan Penelitian.

Dewi, Gustina. 2005. Studi Pemanfaatan Pelayanan Antenatal Terhadap Kelainan Kesehatan pada Ibu hamil di Puskesmas Ulaweng, Kabupaten Bone. http://ridwanamiruddin.com /. Diakses 10 April 2012.

Dinas Kesehatan Kabupaten Solok 2012. Laporan PWS KIA Kabupaten Solok.

Haryono, Tri Joko. 2013. Pemanfaatan Dukun Bayi dan Bidan dalam Pertolongan Persalinan pada Masyarakat Madura. http://psantosofisip.web.unair.ac.id. Diakses 10 April 2012

Jones, Pip. 2010. Pengantar Teori-teori Sosial: Dari Teori Fungsionalisme Hingga Post-Modernisme (terj.) Jakarta: Yayasan Pustaka Obor Indonesia

Kementerian Kesehatan. 2012. Laporan Riset Fasilitas Kesehatan Dasar Puskesmas 2011. Jakarta: Badan Penelitian Pengembangan Kesehatan.

Lolong, Dina Bisara. 2011. Analisa Kematian Ibu dan Neonatal. Jurnal Ekologi Kesehatan, Vol. 10.No.3, September 2011. Jakarta: Badan Litbang Kesehatan.

Masadmin. 2011. "Depkes Siapkan 1,2 Milyar untuk Jampersal". http://mediabidan.com/depkes. Diakses 6 Desember 2012.

Murniati. 2010. "Faktor-faktor yang Berhubungan Dengan Pemanfaatan Pelayanan Antenatal Oleh Ibu Hamil di Kabupaten Tenggara". Medan: Tesis Pasca Sarjana Universitas Sumatera Utara.

Notoatmodjo, Soekidjo. 2010. Promosi Kesehatan: Teori dan Aplikasi. Jakarta: PT Rineka Cipta.

Priyono, B.Herry. 2002. Antony Giddens Suatu Pengantar. Yogyakarta: Keputusan Popular Gramedia Bekerjasama dengan Program Magister Ilmu Religi dan Budaya, Universitas Dharma Yogyakarta.

Puskesmas Batu Bajanjang. 2012. Laporan PWS KIA.

Ristirini. 2007. Upaya Pemberdayaan Masyarakat Miskin di Pedesaan dalam Rangka making Pregnancy Safer (Analisis Situasi Upaya Pelayanan Kesehatan Maternal). Jurnal Kedokteran Indonesia No. 2. Tahun XXXIII, Februari 2007. 
